Article

\title{
Milk Market Integration between Poland and the EU Countries
}

\author{
Monika Roman*(D) and Michał Roman (D) \\ Institute of Economics and Finance, Warsaw University of Life Sciences, 02-787 Warsaw, Poland; \\ michal_roman@sggw.edu.pl \\ * Correspondence: monika_roman@sggw.edu.pl
}

Received: 31 October 2020; Accepted: 18 November 2020; Published: 20 November 2020

\begin{abstract}
Milk is one of the most essential agricultural products in the EU. One of the major milk producers in the EU is Poland. Polish farmers account for supplying $8 \%$ of the total EU production. Nevertheless, Polish milk prices differ from the prices recorded in its western neighbors. The aim of the article has been to evaluate the dynamics of the relationships between milk prices in Poland and in the EU countries. To develop it, the monthly raw milk prices, covering the period January 2005 through December 2018, were applied. The calculations were made for the entire selected period as well as for two sub-periods: 2005-2011 and 2012-2018. The results were used to confirm the milk market integration between Poland and the EU countries. Besides, it must be noted that the relations increased considerably since 2012. The EU countries which have recorded the greatest impact on the prices in Poland are Germany, Ireland, France and Slovakia.
\end{abstract}

Keywords: milk market; Poland; EU; market integration; price volatility; VAR model

\section{Introduction}

The research of a spatial integration of markets is frequently applied to test the market effectiveness, including for agricultural markets [1,2]. The analyses are performed at various spatial aggregation levels which cover the interrelations between regions, macro-regions, countries or even groups of countries. The spatial markets integration is one of the issues used to evaluate the interrelations between the geographically separated objects [3]. It is an especially essential problem in the agricultural market where most products are easily perishable, while their production and consumption areas are often different and distant [4]. The price analyses are most often applied to investigate the spatial integration of markets. The analysis of price relations, the level of price integration and structure facilitate determining whether the geographically separate markets are globalized or regionalized. The prices of products on globalized markets change at the same time, and their integration is a condition necessary for the economic effectiveness $[5,6]$. The information can be needed, e.g., for a full understanding of the markets operation, for developing a policy for a specific market, including a competition policy, taking decisions by decision-makers, the evaluation of the rate of price transmission as well as for facilitating price forecasting $[7,8]$.

For a long time, the spatial price relations on the EU food markets have posed a serious empirical, political and economic problem. The integrated food market will make the EU a more attractive and competitive place for enterprises. The EU Single Market Review provides an attempt at understanding the mechanisms of adapting the prices to the changing economic conditions. However, despite many changes, especially in reference to the internal EU increase in the trade volume, there have been still considerable differences in agri-food product prices. These differences occur even across neighboring countries [9]. Lower agricultural product prices are noted in the countries which joined the EU later, 
such as Poland (PL) [10]. With that in mind, investigating those dependencies and covariance for that type of the country is becoming even more essential.

Much information is available on the theoretical and empirical studies of the interrelations between the agricultural markets [11-13]. Santeramo and Gioia [14] have provided a summary of research into the spatial and vertical price dynamics on agricultural markets. Compliant with the best knowledge, there are also studies on the spatial integration of milk and dairy product markets. Katrakilidis [15] has analyzed the raw milk prices in Germany, France, Belgium, Denmark and the Netherlands during the 1980-2003 period. Using the analysis of cointegration and the Granger causality, he found that those markets are very well integrated. Bakucs et al. [1] have analyzed the spatial integration of milk markets in Poland and in Hungary in 1997-2009. They have demonstrated that the milk price integration between Hungary and Poland in the period studied is not perfect. Fałkowski [16] has analyzed the transmission of prices and the market power with an example of the Polish liquid milk market. With the use of the vector error correction, he found that the transmission of prices between farms and the retail sale are affected by both short- and long-term asymmetries. There are also reports on the milk price integration on the Greek [17] and Turkish [18] markets and the dairy product analysis on the Finnish [19], Spanish [20], Hungarian [21] and Austrian [22] markets. Waldesenbet [23], with the 1993 to 2010 data, has confirmed the transmission of liquid milk prices from producers, wholesalers and retailers in Slovakia. Acosta and Valdes [24] have analyzed the dairy sector in Panama to investigate the level of the vertical transmission of prices between the wholesalers and small producers. They have proven that there is a one-direction transmission of the milk prices from producers to wholesalers and the milk price transmission is asymmetrical and it depends on whether the prices are growing or not. Research was also performed with Russia as an example [25]. Acosta et al. [26] have performed research on a milk price transmission from global to domestic markets. Benedek et al. [27], in 2001-2012, performed an analysis of trade flows in the EU countries. They have demonstrated that the milk trade flows were getting stronger with time. Zhang et al. [28] have performed the analysis of price transmission for the whole milk powder market between the EU, the United States and Oceania. With the 2006-2015 monthly prices, they have confirmed a long-term integration between the objects analyzed. In other studies, the authors have analyzed the prices of dairy products and raw milk for Germany and Switzerland. The aim of the study has been to determine how different protection levels affect the spatial price transmission. The study has shown that the border protection level did not condition the degree and the rate of price transmission but rather the variation in the Swiss product quality [29]. Bakucs et al. [30] have analyzed the spatial price transmission, the relation to the trade in the European dairy sector. In their studies, the authors have confirmed that the milk turnover and the membership in the eurozone contributed to the ideal price transmission, whereas the distance showed a negative effect. Besides, they have found that the price transmission depends on whether a given country is a new member state or the old one. Fousekis [9] has investigated the milk market integration in the EU countries in 2003-2017. Its results suggest that the level of the spatial milk market integration in $16 \mathrm{EU}$ countries is high, which has been confirmed, e.g., with a possibility of the milk prices in most countries to be synchronized with the average milk price in the EU. An exception were the milk prices in Poland, Portugal and in Lithuania. That and also the fact that Poland is one of the new member states fill in the research gap found in the paper and justify a detailed analysis for Poland. The latest analysis of volatility for Poland's milk prices and their integration can be found in the study by Roman [3], providing the 1999-2018 milk market analyses for 16 provinces (the province is Poland's administrative unit). The results have confirmed the existing long-term balance between the prices in Poland. Besides, the price covariance was positively correlated with the distance between the provinces. However, no detailed studies of the milk price integration between Poland and the EU countries have been made.

The key research objective has been to evaluate the processes of spatial raw milk market integration between Poland and the EU countries. As part of the primary objective, the authors have sought answers to the following questions: 
- What is the long-run dependence between the milk prices in Poland and in different EU countries?

- In what EU countries do the milk prices have a dominant effect on the milk price variation in Poland?

- Do the Polish milk prices have an impact on the prices in other EU countries?

- What changes have occurred in the level of price integration on the milk market between Poland and the EU countries?

The article has been divided into the following sections: Section 2 presents the research methodology and describes the research methods applied; Section 3 presents the results of research and a discussion in a few aspects. At the beginning a reference is made to the basic information on the milk market in Poland in terms of the EU, considering the trade exchange. Then the market integration is estimated in terms of price differences and investigates the covariance of prices and the directions of dependence are provided. The article ends up with conclusions presenting especially the research limitations as well as further research prospects.

\section{Materials and Methods}

The research involved the raw milk market, selected on purpose for a few reasons. First of all, milk is an agricultural product produced in every EU member state. According to the European Dairy Association (EDA) [31], milk production accounts for about $22 \%$ of the EU agricultural produce value. Second of all, milk production is an essential item in the Polish agribusiness [32]. Third of all, milk is a homogenous product and it is excellent for estimating the price interactions without any complications resulting from a variation in quality [9,30]. Fourth of all, over the recent years, the milk market in Poland has gone considerable changes, e.g., related to the EU requirement adaptations or changes in the Common Agricultural Policy (CAP), e.g., in terms of abandoning the milk quotas [33].

The integration analysis has been performed with the monthly raw milk prices in 2005-2018 and in two sub-periods; 2005-2011 and 2012-2018. The sub-periods were selected based on the time series analysis and a considerable decrease in the milk price differences in Poland when compared with the milk prices in the EU countries after 2011. Price logarithms were included in the calculations. It is a common practice in this type of analysis $[1,3,4,9]$. The data at the country level has been derived from the Milk Market Observatory [10]. With the preliminary time series analysis, next to Poland, another 24 countries were selected; following the decreasing milk production, they were (Figure 1): Germany (DE), France (FR), the United Kingdom of Great Britain and Northern Ireland (UK), Italy (IT), the Netherlands (NL), Spain (ES), Ireland (IE), Denmark (DK), Belgium (BE), Austria (AT), the Czech Republic (CZ), Sweden (SE), Finland (FI), Portugal (PT), Hungary (HU), Greece (EL), Lithuania (LT), Bulgaria (BG), Latvia (LV), Slovakia (SK), Estonia (EE), Slovenia (SI), Luxemburg (LU) and Cyprus (CY). In 2018 the total amount of milk produced in the EU was 168.4 million tons and it was $10 \%$ higher than in 2005.

Figure 2 presents the basic raw milk price characteristics broken down into the sub-periods. Interestingly, the mean monthly milk prices ranged from $25 \mathrm{EUR} / 100 \mathrm{~kg}$ (in Lithuania) to $52 \mathrm{EUR} / 100 \mathrm{~kg}$ (in Cyprus) for the entire period. The milk prices in Cyprus were definitely higher than in the other EU countries. The average high milk prices were noted also in Greece $(40.2 \mathrm{EUR} / 100 \mathrm{~kg})$ and in Finland (39.9 EUR/100 kg), while the lowest average milk prices for the entire period were recorded in Lithuania, Latvia $(25.8 \mathrm{EUR} / 100 \mathrm{~kg}$ ) and in Hungary $(28.1 \mathrm{EUR} / 100 \mathrm{~kg})$. As for the comparison of the two sub-periods, one must note some decrease in the variation in average prices in all the countries, accompanied by an increase in prices.

To verify the aim of the paper, various methods have been applied. Descriptive statistics have been used to present the basic information on variables. Augmented Dickey-Fuller (ADF) tests were applied to assess the stationarity of variables [35]. The null hypothesis of the unit root test is that the time series contains a unit root and hence is non-stationary. A unit root must be checked to avoid the problem of apparent regression. The optimal lag length for the tests was selected with the Akaike Information Criterion (AIC). With that in mind, the time series for the milk prices were stationary, 
$\mathrm{I}(0)$ (Table 1) and, to evaluate the level of integration, the price differences and the price correction, the analysis of correlation and the Granger causality test were used. The analysis of price differences and the analysis of their adaptations can be indirectly applied to draw conclusions on the integration of markets. Should there occur higher price differences between the markets analyzed, the integration of markets is lower. Besides, the differences often increase with an increase in the distance between the markets analyzed [3]. The analysis of price correlation is one of the simplest methods to assess the level of the integration of markets [36].

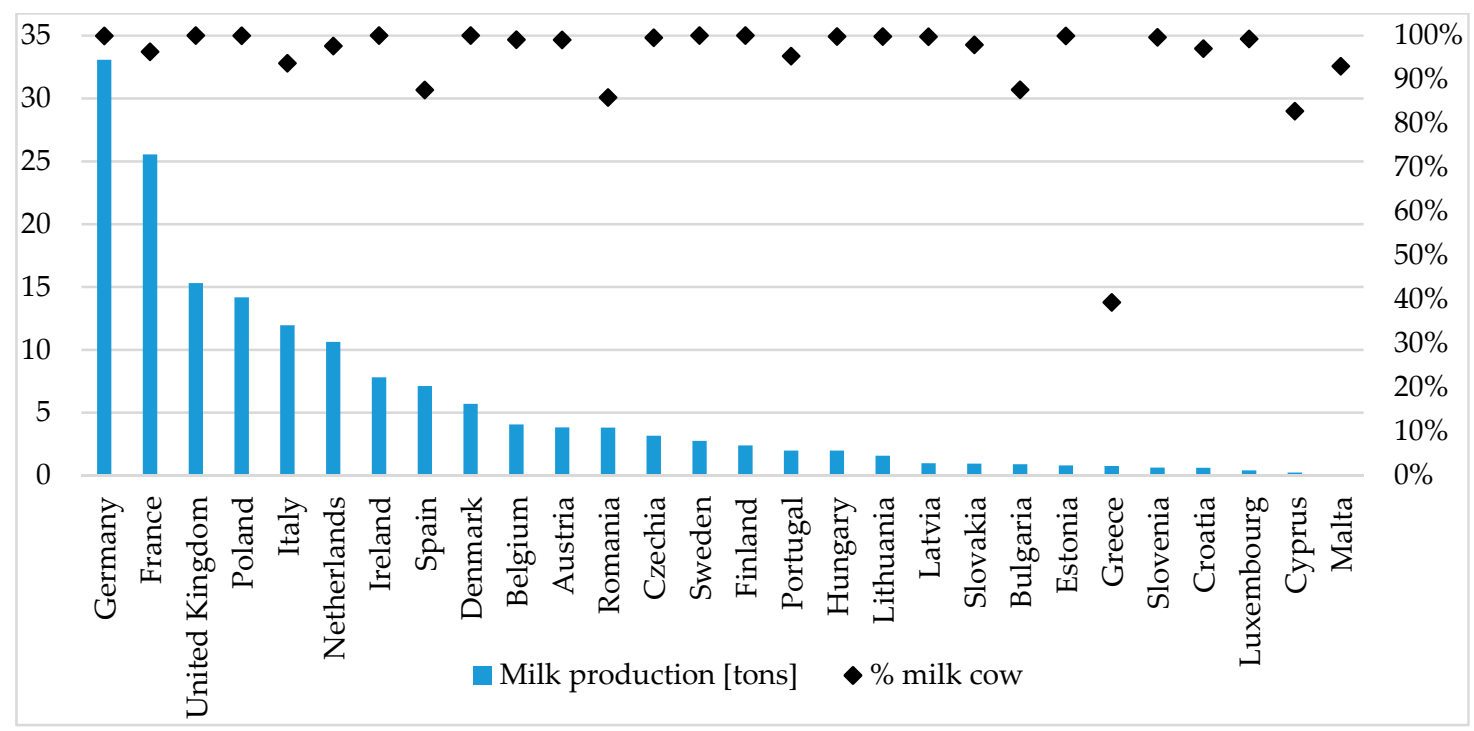

Figure 1. Raw milk production in the EU. Source: own calculations [34].

Table 1. Unit root test results.

\begin{tabular}{cccc}
\hline Country & Stat. & $p$-Value & Decision \\
\hline PL & -2.9849 & 0.0363 & $\mathrm{I}(0)$ \\
BE & -4.0946 & 0.0014 & $\mathrm{I}(0)$ \\
BG & -3.2482 & 0.0174 & $\mathrm{I}(0)$ \\
CZ & -3.3339 & 0.0135 & $\mathrm{I}(0)$ \\
DK & -3.4842 & 0.0084 & $\mathrm{I}(0)$ \\
DE & -3.6346 & 0.0061 & $\mathrm{I}(0)$ \\
EE & -3.3970 & 0.0126 & $\mathrm{I}(0)$ \\
IE & -3.4508 & 0.0108 & $\mathrm{I}(0)$ \\
EL & -2.4057 & 0.1417 & $\mathrm{I}(1)$ \\
ES & -2.2651 & 0.1844 & $\mathrm{I}(1)$ \\
FR & -3.6545 & 0.0058 & $\mathrm{I}(0)$ \\
IT & -2.9601 & 0.0413 & $\mathrm{I}(0)$ \\
CY & -1.8627 & 0.3491 & $\mathrm{I}(1)$ \\
LV & -3.2118 & 0.0213 & $\mathrm{I}(0)$ \\
LT & -3.0500 & 0.0329 & $\mathrm{I}(0)$ \\
LU & -2.9512 & 0.0422 & $\mathrm{I}(0)$ \\
HU & -3.3071 & 0.0163 & $\mathrm{I}(0)$ \\
NL & -3.5322 & 0.0084 & $\mathrm{I}(0)$ \\
AT & -2.9608 & 0.0412 & $\mathrm{I}(0)$ \\
PT & -3.0672 & 0.0314 & $\mathrm{I}(0)$ \\
SI & -3.4869 & 0.0097 & $\mathrm{I}(0)$ \\
SK & -3.5828 & 0.0072 & $\mathrm{I}(0)$ \\
FI & -3.3735 & 0.0135 & $\mathrm{I}(0)$ \\
SE & -3.3862 & 0.0130 & $\mathrm{I}(0)$ \\
UK & -2.9638 & 0.0409 & $\mathrm{I}(0)$ \\
\hline
\end{tabular}

Source: own calculations [10]. 


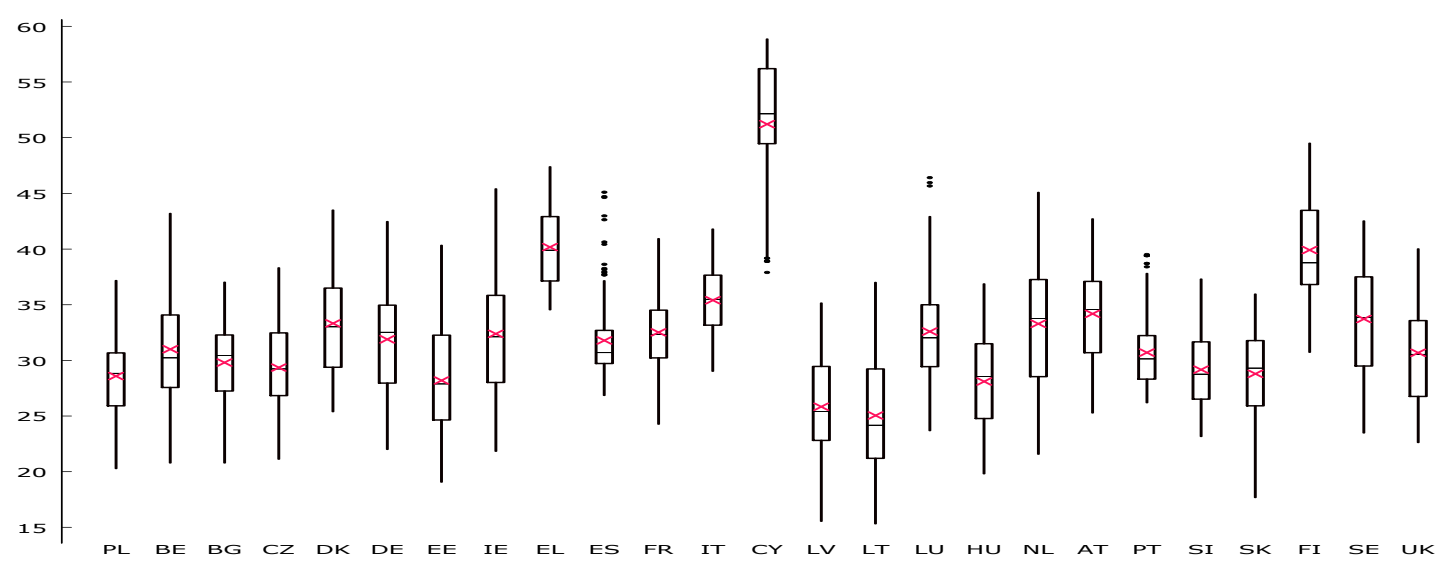

(a)

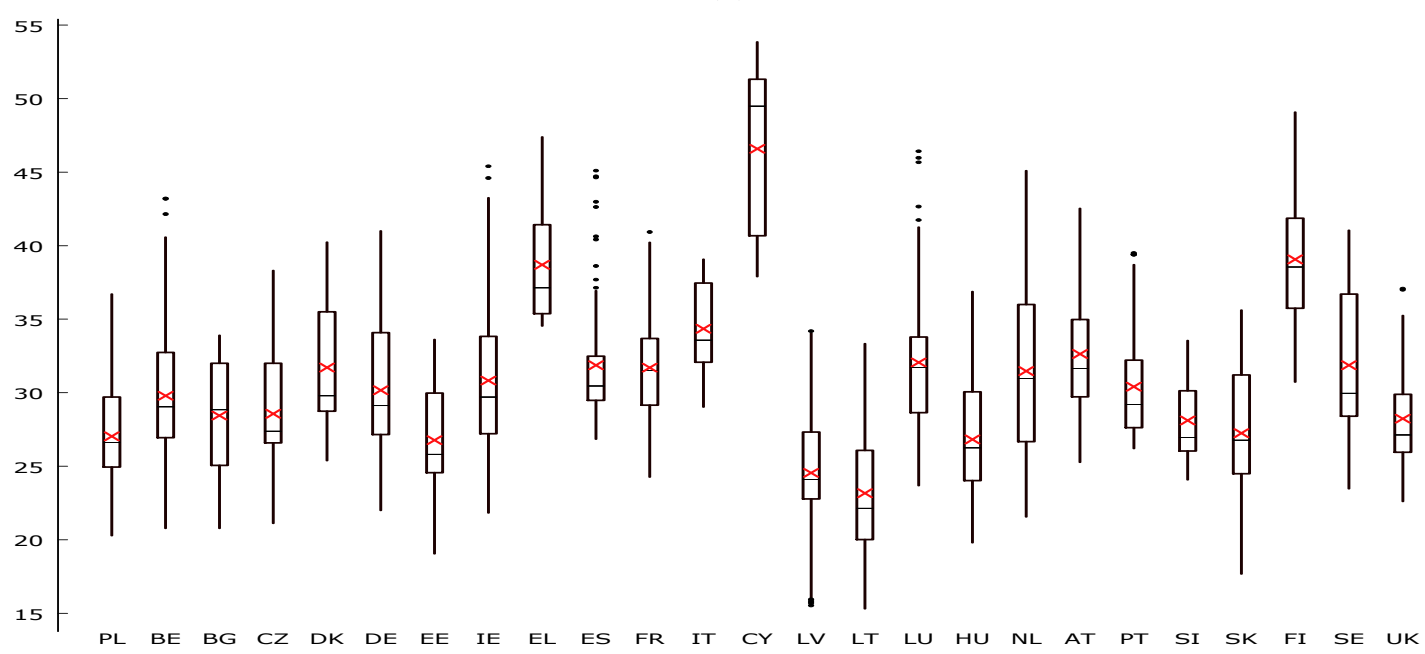

(b)

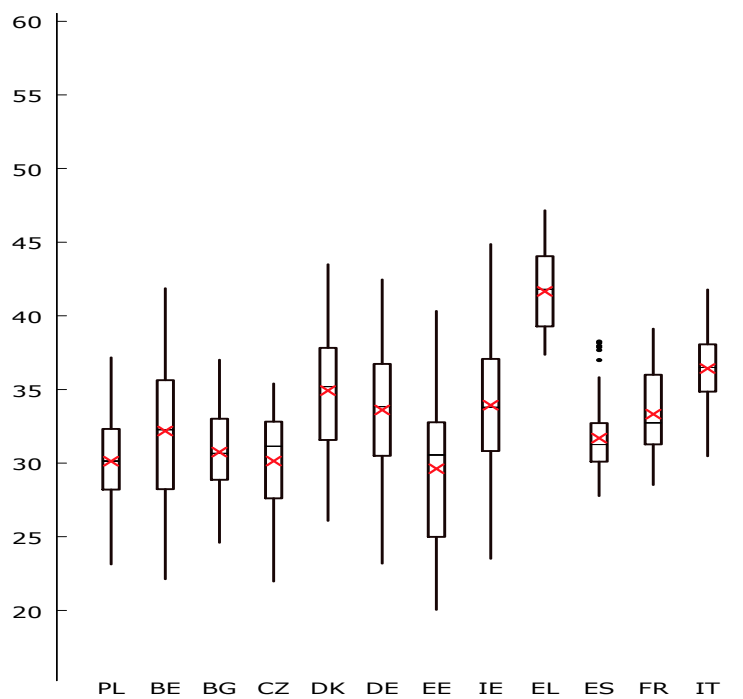

自

(c)

Figure 2. Basic raw milk price characteristics across the countries (EUR/100 kg): (a) in 2005-2018, (b) in 2005-2011, (c) in 2012-2018. Source: own calculations [10]. 
The analysis of the relations between the shaping of the variables may indicate that they influence each other and the course of the relationship is two-way. This requires the application of the Vector AutoRegresive (VAR) methodology developed by Sims [37]. The basic form of the VAR model is as follows [38,39]:

$$
X_{t}=A_{0} d_{t}+\sum_{i=1}^{r} A_{i} X_{t-i}+e_{t},
$$

where: $X_{t}$-vector of observations on the current values of the variables; $d_{t}$-vector $k+1$ deterministic components equal to (intercept, time variable, etc.); $A_{0}$-matrix of parameters with $d_{t}$ vector variables; $A_{i}$-parameter matrix with delayed variables of the vector $\mathrm{x}_{t}$, where the maximum order of the lag is $r$; $e_{t}$-contains the residual vectors of the model equations.

The Granger causality test is used to determine the cause-and-effect relations in the economy. In the test "variable $\mathrm{x}$ is the Granger cause of variable $\mathrm{y}$ when the values of variable $\mathrm{y}$ can be more accurately foreseen, considering the future value of variable $x$ than when disregarding those values. In the Granger causality test, $\mathrm{H} 0$ is tested: all coefficients $\beta_{k}$ equal zero, which is interpreted as a lack of causality". The Granger causality test can be given as follows [40]:

$$
\begin{aligned}
& Y_{t}=\beta_{0}+\sum_{j=1}^{m} \beta_{j} Y_{t-j}+\sum_{k=l}^{n} \beta_{k} X_{t-k}+u_{t}, \\
& X_{t}=\beta_{0}+\sum_{j=1}^{m} \beta_{j} X_{t-j}+\sum_{k=l}^{n} \beta_{k} Y_{t-k}+u_{t},
\end{aligned}
$$

where: $Y_{t}$ —values of variable $Y ; X_{t}$ —values of variable $X ; \beta$-structural model parameters; $t$-time variable; $u$-random model element.

\section{Results and Discussion}

\subsection{Trade Exchange as an Expression of the Integration of Markets}

The trade exchange is one of the basic measures showing the level of integration of separate markets. The product flow stands for a flow of demand-supply impulses across the countries [41]. Even though a low share of the Polish milk production is exported (about $4 \%$ in 2018), a gradual and considerable increase in trading of this product since 2005 can been observed (Table 2). Milk is an easily perishable product and so there are essential limitations to its transport. Interestingly however, progress in logistics has considerably enhanced the possibility of transporting milk further [42].

Table 2. Milk exports from Poland to the EU countries (in thousand USD).

\begin{tabular}{ccccccc}
\hline Country & \multicolumn{2}{c}{2005} & \multicolumn{2}{c}{$\mathbf{2 0 1 2}$} & \multicolumn{2}{c}{$\mathbf{2 0 1 8}$} \\
\hline & Export & $\mathbf{\%}$ & Export & \% & Export & \% \\
\hline Germany & 46.091 & 93.26 & 99.267 & 76.56 & 173.253 & 71.91 \\
United Kingdom & 3 & 0.01 & 4197 & 3.24 & 16.307 & 6.77 \\
Lithuania & 1.148 & 2.32 & 3.599 & 2.78 & 15.589 & 6.47 \\
Bulgaria & 4 & 0.01 & 749 & 0.58 & 6.200 & 2.57 \\
Latvia & 10 & 0.02 & 94 & 0.07 & 5.633 & 2.34 \\
Romania & 0 & 0.00 & 2620 & 2.02 & 4.884 & 2.03 \\
Greece & 0 & 0.00 & 925 & 0.71 & 3.848 & 1.60 \\
Italy & 61 & 0.12 & 6206 & 4.79 & 3.074 & 1.28 \\
Hungary & 322 & 0.65 & 5643 & 4.35 & 2.578 & 1.07 \\
Others & 1.782 & 3.61 & 6365 & 4.91 & 9.552 & 3.96 \\
\hline
\end{tabular}

Source: own calculations [34]. 
Nevertheless, due to the distance, the key importers of the Polish milk are the EU countries, mostly Germany. It must be noted, however, that still back in 2005 almost $100 \%$ of the milk exported reached the EU, almost $93 \%$ of which went to Germany, whereas in 2018 almost $86 \%$ of the milk exported reached the EU countries and only about $62 \%$ to Germany. Analyzing the changes in milk imports, interestingly, the milk came only from the EU countries (Table 3). The key milk suppliers were, in particular, Lithuania, Germany, the Czech Republic, that is, Poland's closest neighbors.

Table 3. Milk imports to Poland from the EU countries (in thousand USD).

\begin{tabular}{ccccccc}
\hline Country & \multicolumn{2}{c}{2005} & \multicolumn{2}{c}{$\mathbf{2 0 1 2}$} & \multicolumn{2}{c}{$\mathbf{2 0 1 8}$} \\
\hline & Import & $\mathbf{\%}$ & Import & $\mathbf{\%}$ & Import & $\mathbf{\%}$ \\
\hline Lithuania & 0 & 0.00 & 35218 & 63.26 & 26260 & 44.19 \\
Germany & 101 & 23.49 & 10267 & 18.44 & 14916 & 25.10 \\
Czechia & 148 & 34.42 & 8223 & 14.77 & 11651 & 19.61 \\
Austria & 0 & 0.00 & 461 & 0.83 & 2895 & 4.87 \\
Belgium & 0 & 0.00 & 721 & 1.30 & 1064 & 1.79 \\
Netherlands & 0 & 0.00 & 322 & 0.58 & 906 & 1.52 \\
France & 181 & 42.09 & 324 & 0.58 & 752 & 1.27 \\
Hungary & 0 & 0.00 & 28 & 0.05 & 620 & 1.04 \\
Slovakia & 0 & 0.00 & 48 & 0.09 & 313 & 0.53 \\
Others & 0 & 0.00 & 62 & 0.11 & 44 & 0.07 \\
\hline
\end{tabular}

Source: own calculations [34].

\subsection{Price Differences as an Expression of The Integration of Markets}

During the second stage the analysis of milk market integration was performed in terms of price differences. The mean absolute deviations in the logarithms of Polish milk prices to the prices in the EU for the entire period ranged from 3\% to $8.5 \%$, which accounted for the average of $4.8 \%$ (Figure 3). Additionally, one must note the two sub-periods of the greatest deviations in 2009-2010 and 2015-2017. The first period could have resulted from a global economic situation due to crisis. The high price differences in the second period could have been due the CAP changes, especially abandoning the milk quotas and the period of getting adapted to the new milk market situation [33].

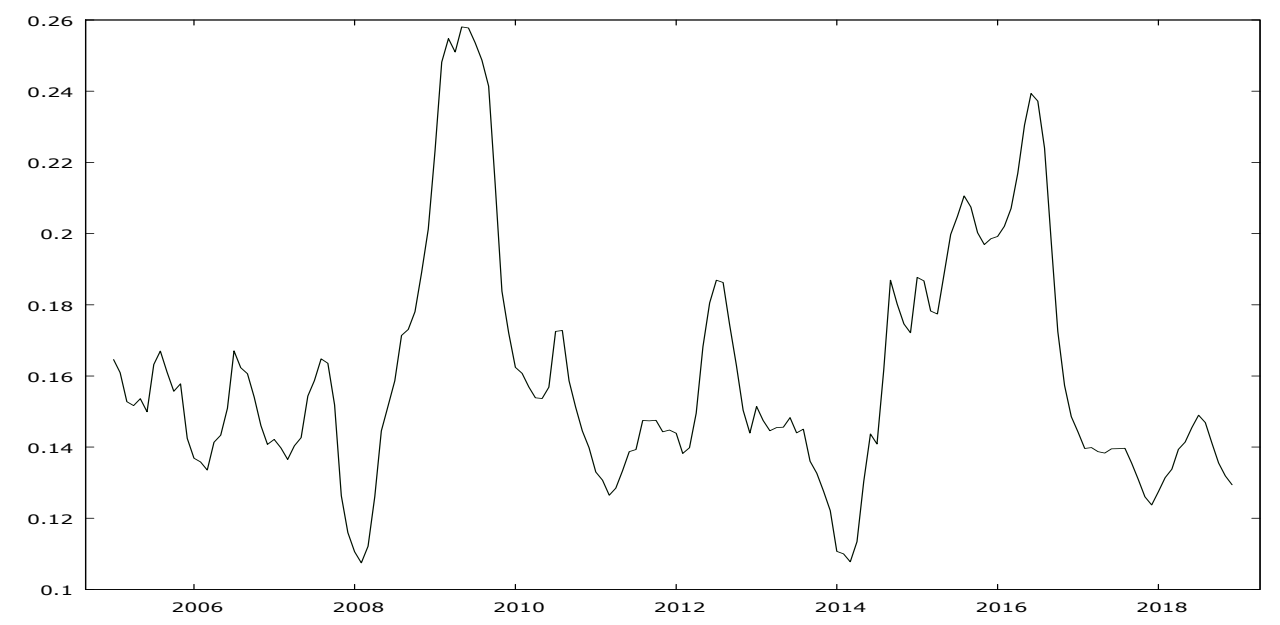

Figure 3. Mean absolute deviations in the logarithms of milk prices in the European Union from the prices in Poland. Source: own calculations [10].

A more thorough understanding of the price differences requires presenting the typical cases which can occur on the market. The first one is when the prices in Poland are higher than in other countries, which is the case only between Poland and Lithuania (Figure 4a). In the second case, 
the differences in prices oscillate around zero, which was recorded for the Czech Republic, Slovakia (Figure 4b), Estonia, Latvia and Hungary, which is the countries which joined the EU the same year as Poland. The similarity in the price variation depending on the time of joining the EU has been stressed by, e.g., Bakucs et al. [30]. Besides, one must note that the group includes all the EU countries found in a close vicinity of Poland, which can be due the fact that milk is indeed a perishable product and, as such, it shows limited transport possibilities. In the third case, the prices in Poland are lower than in other countries. It is the case for the other countries, including the ones provided in 4c (Germany).

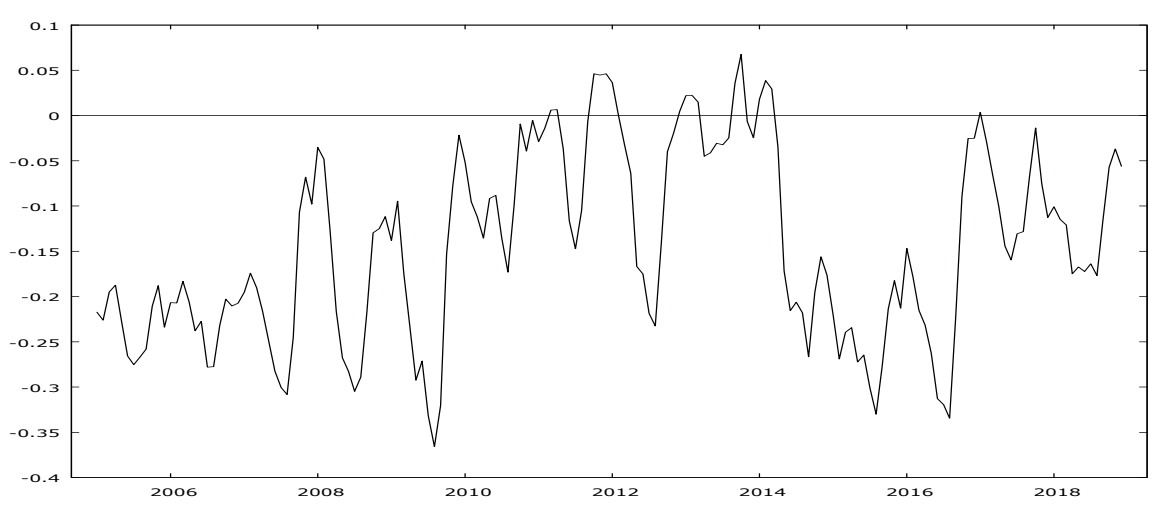

(a)

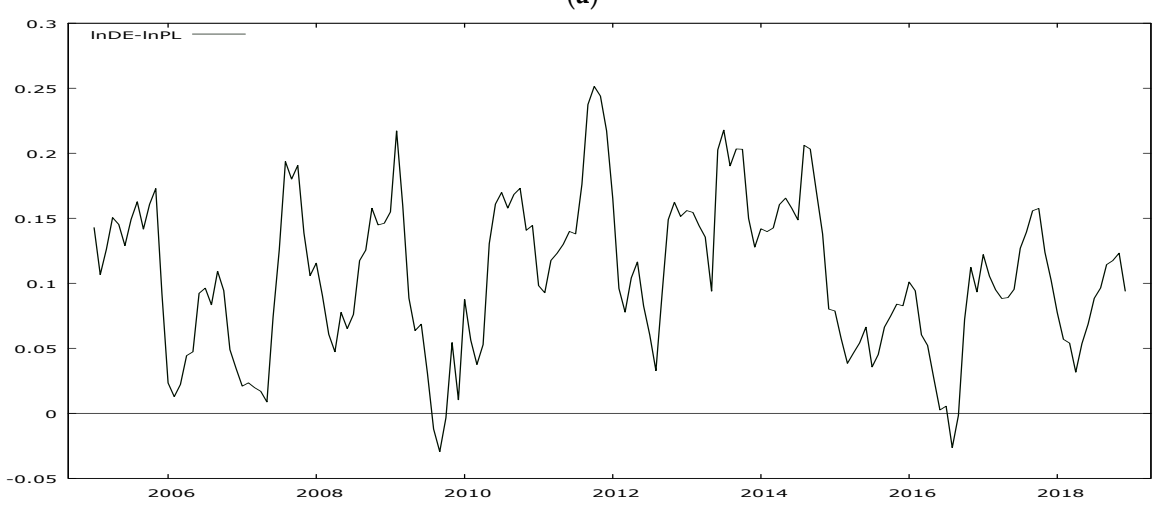

(b)

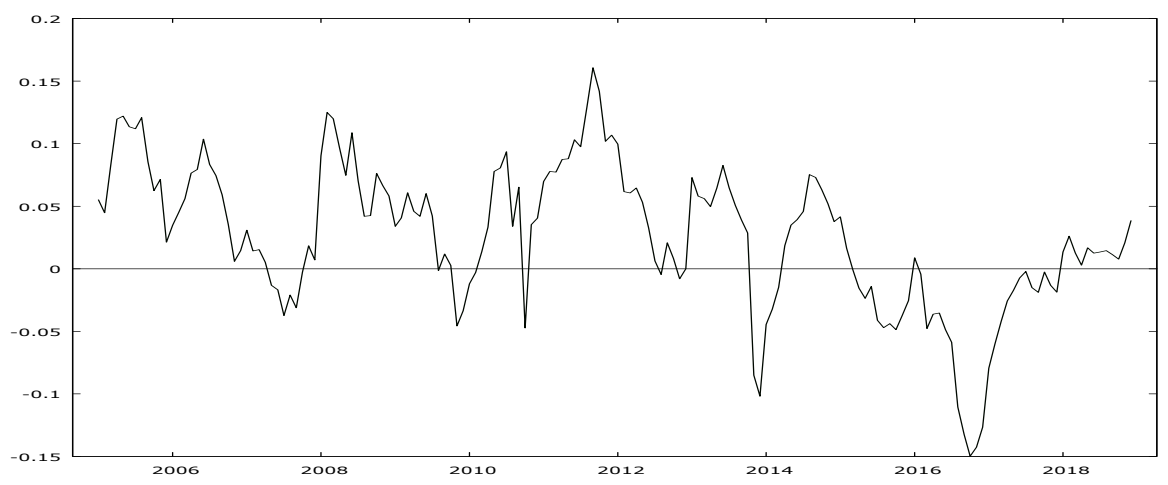

(c)

Figure 4. Differences between (a) Lithuanian (b) German (c) Slovakian milk prices and Polish milk prices in 2005-2018. Source: own calculations [10].

One can note that in some of the cases, the price differences decreased. The price difference decrease over time is probably a consequence of the effect of various factors, e.g., an increase in foreign trade in milk with the EU countries, but also an increase in dairy product trade volume. Besides, the change in the differences must have been affected by a more efficient flow of information between respective EU countries as well as a growing integration of prices [9,27]. 


\subsection{Correlation between the Prices and the Direction of the Dependence}

The Spearman's rank coefficients of correlation between time series (logarithms and the first logarithmic increments) were calculated (Table 4). The coefficients of correlation for the price logarithms for the entire period ranged from 0.42 to 0.92 , and for the first increments-from 0.20 to 0.73 . The lowest values of the coefficient of correlation between the Polish milk prices were noted for the prices in Finland and in Cyprus. The highest values of the coefficient of correlation were reported for Germany, the Czech Republic and Slovakia. As for the comparison of the two sub-periods, one must note that the mean values of the coefficient of correlation for all the countries for the analysis of the first differences increased slightly from 0.49 to 0.59 . However, as for the countries with the highest coefficient values, one must observe the maintained tendency in both periods for Germany, Hungary, Slovakia, and then for the Czech Republic, Belgium, and in the second period-also for Lithuania and Latvia. The analyses facilitate formulating the conclusion that the closer the countries are located, the higher the covariance of prices (Figure 5). A similar conclusion about the role of distance can be found in other publications $[3,30]$.

Table 4. Spearman's rank correlation coefficient between the milk prices in Poland and in the EU countries (logarithm prices).

\begin{tabular}{|c|c|c|c|c|c|c|}
\hline \multirow[b]{2}{*}{ Country } & $2005-2018$ & $2005-2011$ & $2012-2018$ & 2005-2018 & $2005-2011$ & 2012-2018 \\
\hline & \multicolumn{3}{|c|}{$\begin{array}{c}\text { PL } \\
\text { Level }\end{array}$} & \multicolumn{3}{|c|}{$\begin{array}{c}\text { PL } \\
\text { First Differences }\end{array}$} \\
\hline $\mathrm{BE}$ & 0.88 & 0.90 & 0.86 & 0.67 & 0.62 & 0.72 \\
\hline BG & 0.67 & 0.60 & 0.68 & 0.52 & 0.42 & 0.60 \\
\hline $\mathrm{CZ}$ & 0.90 & 0.90 & 0.90 & 0.66 & 0.63 & 0.69 \\
\hline DK & 0.86 & 0.79 & 0.83 & 0.49 & 0.50 & 0.48 \\
\hline DE & 0.91 & 0.87 & 0.90 & 0.62 & 0.51 & 0.70 \\
\hline $\mathrm{EE}$ & 0.85 & 0.85 & 0.85 & 0.57 & 0.51 & 0.63 \\
\hline IE & 0.87 & 0.84 & 0.85 & 0.44 & 0.41 & 0.47 \\
\hline EL & 0.61 & 0.62 & $0.11^{\mathrm{a}}$ & 0.39 & 0.36 & 0.44 \\
\hline ES & 0.72 & 0.68 & 0.71 & 0.61 & 0.57 & 0.64 \\
\hline FR & 0.75 & 0.60 & 0.81 & 0.15 & $0.14^{\mathrm{a}}$ & $0.16^{\mathrm{a}}$ \\
\hline IT & 0.79 & 0.75 & 0.72 & 0.42 & 0.26 & 0.55 \\
\hline CY & 0.50 & 0.26 & 0.28 & 0.20 & $0.14^{\mathrm{a}}$ & 0.31 \\
\hline $\mathrm{LV}$ & 0.87 & 0.91 & 0.86 & 0.59 & 0.49 & 0.69 \\
\hline $\mathrm{LT}$ & 0.88 & 0.87 & 0.85 & 0.63 & 0.55 & 0.72 \\
\hline LU & 0.80 & 0.76 & 0.87 & 0.62 & 0.53 & 0.71 \\
\hline HU & 0.90 & 0.92 & 0.79 & 0.73 & 0.70 & 0.75 \\
\hline NL & 0.85 & 0.75 & 0.89 & 0.45 & 0.32 & 0.62 \\
\hline AT & 0.89 & 0.82 & 0.89 & 0.61 & 0.53 & 0.70 \\
\hline PT & 0.70 & 0.67 & 0.63 & 0.45 & 0.42 & 0.46 \\
\hline SI & 0.80 & 0.74 & 0.77 & 0.58 & 0.50 & 0.67 \\
\hline SK & 0.92 & 0.94 & 0.87 & 0.65 & 0.62 & 0.70 \\
\hline FI & 0.42 & 0.47 & 0.32 & 0.23 & $0.20^{\mathrm{a}}$ & 0.26 \\
\hline SE & 0.84 & 0.82 & 0.78 & 0.53 & 0.51 & 0.55 \\
\hline UK & 0.77 & 0.77 & 0.52 & 0.45 & 0.31 & 0.57 \\
\hline
\end{tabular}

a Statistically insignificant at the level of 0.05 . Source: own calculations [10].

In order to verify the effects of price transmission, the tests of the significance of the coefficients were carried out with the use of the VAR model. Detailed results of the analysis are presented in Table A1 in Appendix A. It can be seen that future milk prices in Poland are significantly affect by the past milk prices in Poland (with one and two lags). In addition, the results suggest that there is significant transmission of milk prices from EU countries, with the exception of Estonia and Latvia. On the other hand, past milk prices in Poland have a significant impact on shaping future prices in 
EU countries, with the exception of milk prices in Belgium, Germany, France, Slovenia, Finland and Great Britain.

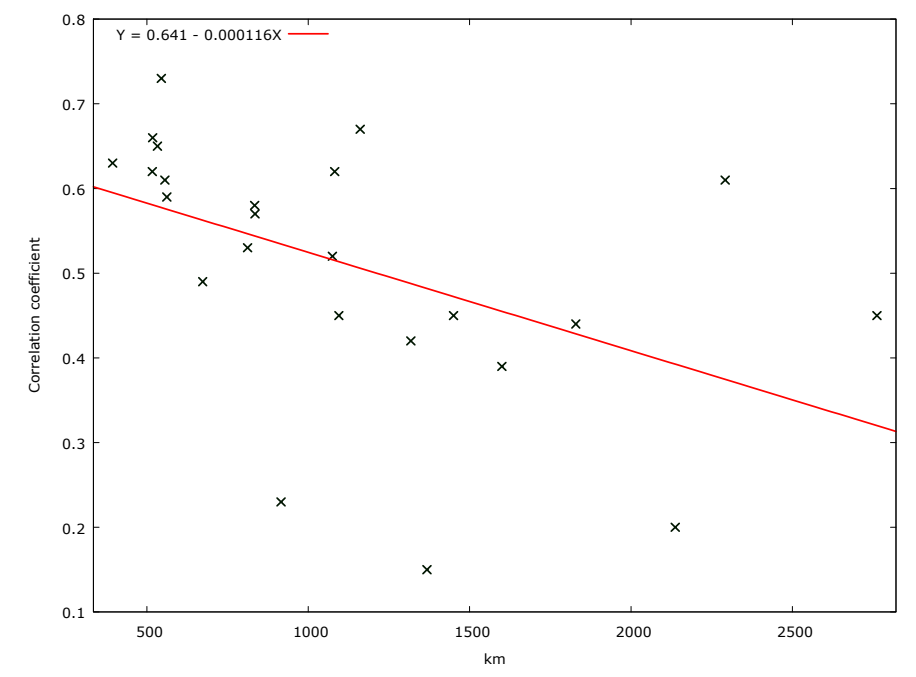

Figure 5. Spearman's rank correlation coefficients between the prices (logarithmic increments) and the distance between the countries. Source: own calculations.

The next step involved the Granger causality test for logarithm milk prices in Poland and in the EU countries in 2005-2018 (Table 5). In the Granger causality test, the zero hypothesis, assuming a lack of causality between the series of milk prices in Poland and the series of milk prices in other EU countries, should be rejected, except for the relation between Poland and Greece. At the significance level at $p=0.05$ one can note that in 17 out of 21 countries a two-way causality (marked with $\leftrightarrow$ ) is found, while in the other four countries it is a one-way causality (marked with $\rightarrow$ or $\leftarrow$ ). Thus, the milk prices on the Polish market, in most cases, are considered to be affected by the prices in the other EU countries in the entire period analyzed, which can be due to a considerable position of Poland (the fourth biggest producer) in the EU milk production.

To verify the possible changes in the directions of the impact in time, there were analyzed two sub-periods, 2005-2011 and 2012-2018. In the light of the Granger causality tests, for 2005-2011 one must reject the zero hypothesis assuming a lack of causality between the series of milk prices in Poland and the series of milk prices in the other EU countries, except for the Poland-Italy relation. In six cases one can note a two-way causality, while in the other cases we face a one-way causality. Besides, only in five cases the milk prices in Poland were getting adapted to the milk prices in the other EU countries.

In the second sub-period, the zero hypothesis assuming a lack of causality between the series of milk prices in Poland and the series of milk prices in the other EU countries should be rejected, except for the Poland-Denmark relationship. Three cases demonstrate a two-way causality and as for the other countries-a single-way causality.

The results also suggest that the countries which are located closer to Poland have a greater impact on the variation in milk prices in Poland. From the commercial perspective, it is Germany which is the most important dairy market for Poland. Germany imports most Polish milk and dairy products [10], which helps keeping the prices. In the entire period, and mostly in 2012-2018, the milk prices in Germany affected the price variation in Poland. Besides, already Katrakilidis [15] confirmed a dominant importance of the German milk market in Europe and the effect of milk prices on other markets. The importance of Germany has been confirmed in other studies [9]. Besides, the significance of the German market for the Polish milk market also seems compliant with the results reported by Benedek et al. [27], who have demonstrated that stronger market relations are one of the necessary market integration conditions. The important markets which affected the adjustment of prices in Poland in the second period were also Ireland, France and Slovakia. Furthermore, the importance of those countries increased in the second period. 
Table 5. Granger causality F-test.

\begin{tabular}{|c|c|c|c|c|c|c|c|c|c|}
\hline \multicolumn{4}{|c|}{ 2005-2018 } & \multicolumn{2}{|c|}{ 2005-2011 } & \multicolumn{4}{|c|}{ 2012-2018 } \\
\hline & $\begin{array}{c}\text { H0: } \\
\text { PL } \neq> \\
\text { Country UE }\end{array}$ & $\begin{array}{c}\text { H0: } \\
\text { Country UE } \\
\neq>\text { PL }\end{array}$ & Direction & $\begin{array}{c}\text { H0: } \\
\text { PL } \neq> \\
\text { Country UE }\end{array}$ & $\begin{array}{c}\text { H0: } \\
\text { Country } \\
\text { UE } \neq>\text { PL }\end{array}$ & Direction & $\begin{array}{c}\text { H0: } \\
\text { PL } \neq> \\
\text { Country UE }\end{array}$ & $\begin{array}{c}\text { H0: } \\
\text { Country UE } \\
\neq>\text { PL }\end{array}$ & Direction \\
\hline $\mathrm{BE}$ & 0.063 & $17.205^{* * *}$ & $\rightarrow$ & 0.063 & $16.218^{* * *}$ & $\leftarrow$ & 0.008 & $5.984^{* *}$ & $\leftarrow$ \\
\hline BG & $3.924^{* * *}$ & $2.196^{* *}$ & $\leftrightarrow$ & $3.853 * *$ & 0.845 & $\rightarrow$ & $5.648^{* *}$ & $6.094^{* *}$ & $\leftrightarrow$ \\
\hline $\mathrm{CZ}$ & $6.055^{* * *}$ & $3.581^{* *}$ & $\leftrightarrow$ & $5.487^{* * *}$ & 2.037 & $\rightarrow$ & $7.833^{* * *}$ & 1.579 & $\rightarrow$ \\
\hline DK & $12.181^{* * *}$ & $6.219^{* * *}$ & $\leftrightarrow$ & $6.439^{* * *}$ & $5.139^{* * *}$ & $\leftrightarrow$ & 2.299 & 2.917 & - \\
\hline $\mathrm{DE}$ & $3.613^{* *}$ & $14.59^{* * *}$ & $\leftrightarrow$ & $12.53^{* * *}$ & 0.273 & $\rightarrow$ & 1.481 & $12.535^{* * *}$ & $\leftarrow$ \\
\hline $\mathrm{EE}$ & $14.079 * * *$ & 2.054 & $\leftarrow$ & $6.089^{* * *}$ & 1.629 & $\rightarrow$ & $21.944^{* * *}$ & 0.207 & $\rightarrow$ \\
\hline IE & $4.692 * * *$ & $5.874^{* * *}$ & $\leftrightarrow$ & 3.242 & $9.192 * * *$ & $\leftarrow$ & $3.771 * * *$ & $13.216^{* * *}$ & $\leftrightarrow$ \\
\hline FR & $6.332 * * *$ & $2.774^{* * *}$ & $\leftrightarrow$ & $3.116^{* *}$ & $2.787^{* *}$ & $\leftrightarrow$ & 0.035 & $12.061^{* * *}$ & $\leftarrow$ \\
\hline IT & $13.073^{* * *}$ & $4.975^{* * *}$ & $\leftrightarrow$ & 3.596 & 2.522 & - & $7.224 * * *$ & 2.6 & $\rightarrow$ \\
\hline LV & $5.797^{* * *}$ & 1.241 & $\rightarrow$ & $5.103^{* * *}$ & 0.695 & $\rightarrow$ & $9.935^{* * *}$ & 0.803 & $\rightarrow$ \\
\hline $\mathrm{LT}$ & $6.739 * * *$ & 3.759 & $\leftrightarrow$ & $6.941^{* * *}$ & $4.561^{* * *}$ & $\leftrightarrow$ & $4.793^{* * *}$ & $2.475^{* *}$ & $\leftrightarrow$ \\
\hline LU & $4.254^{* * *}$ & $2.565^{* *}$ & $\leftrightarrow$ & 2.371 & $5.336^{* * *}$ & $\leftarrow$ & $6.385^{* *}$ & 0.519 & $\rightarrow$ \\
\hline $\mathrm{HU}$ & $9.051^{* * *}$ & $5.6489 * * *$ & $\leftrightarrow$ & $14.542^{* * *}$ & 2.808 & $\rightarrow$ & 2.234 & $4.743^{* *}$ & $\leftarrow$ \\
\hline NL & $9.887^{* * *}$ & $3.273^{* *}$ & $\leftrightarrow$ & $2.671^{* *}$ & $2.418^{* *}$ & $\leftrightarrow$ & $5.151 * *$ & 0.921 & $\rightarrow$ \\
\hline AT & $6.975^{* * *}$ & $3.859^{* * *}$ & $\leftrightarrow$ & 2.217 & $3.950 * * *$ & $\leftarrow$ & $6.956^{* * *}$ & 0.941 & $\rightarrow$ \\
\hline $\mathrm{PT}$ & $11.656^{* * *}$ & $4.008^{* * *}$ & $\leftrightarrow$ & $6.279^{* *}$ & $5.295 * *$ & $\leftrightarrow$ & $19.216^{* * *}$ & 0.118 & $\rightarrow$ \\
\hline SI & $4.029 * * *$ & $3.122 * *$ & $\leftrightarrow$ & $4.563^{* * *}$ & $3.975^{* * *}$ & $\leftrightarrow$ & 1.468 & $4.131^{* * *}$ & $\leftarrow$ \\
\hline SK & $10.439 * * *$ & $2.713^{* *}$ & $\leftrightarrow$ & $16.261^{* * *}$ & 1.461 & $\rightarrow$ & 1.786 & $8.735^{* * *}$ & $\leftarrow$ \\
\hline FI & $2.730^{* * *}$ & 1.267 & $\rightarrow$ & $3.316^{* * *}$ & 2.108 & $\rightarrow$ & 3.383 ** & 2.246 & $\rightarrow$ \\
\hline SE & $20.939 * * *$ & $3.123^{* *}$ & $\leftrightarrow$ & $33.233^{* * *}$ & 3.448 & $\rightarrow$ & $5.055^{* *}$ & 1.175 & $\rightarrow$ \\
\hline UK & $2.982^{* * *}$ & $4.471^{* * *}$ & $\leftrightarrow$ & 0.294 & $7.912^{* * *}$ & $\leftarrow$ & 2.116 & $7.139^{* * *}$ & $\leftarrow$ \\
\hline
\end{tabular}

${ }^{* *}$ Significant at $5 \%$ level, ${ }^{* * *}$ significant at $1 \%$ level. Source: own calculations [10]. 


\section{Conclusions}

The analysis of milk market integration, including the price variation, is a key aspect of agriculture economics. Price fluctuations affect the access to food and so the price analysis is essential from the point of view of the consumers [43]. Besides, identifying the transmission mechanism and the speed at which the domestic or even global milk prices are transferred to respective markets are necessary, e.g., for developing the adequate political means, indispensable to limit the milk price fluctuations and poverty and to guarantee the food security [26].

The aim of the paper has been to assess the level of integration between the milk prices in Poland and in the other EU countries. The analyses were performed applying the monthly raw milk prices from 24 countries in 2005-2018. The empirical results demonstrate that the prices on the Polish milk market differ significantly from the prices of the leading EU milk producers. Despite the recent decrease in the price differences, as compared with the leaders, the milk prices in Poland have not been fully synchronized yet. This is how the findings of other authors $[9,27]$ have been confirmed. It should be expected that in the future the importance of the Polish milk market in the EU will increase. Thus, Poland will not only be one of the leaders in milk production, but will also determine the price differentiation in the EU countries.

Interestingly, the variation in milk prices in various countries comes from many factors specific for a given territory as well as from the factors common for all the EU members. It is confirmed by reflecting the power of covariance between the prices in Poland and the UE-28 average. Even though the milk prices in Poland are lower than in the leading milk producing countries in the EU, market integration is found. Besides, one must expect that the milk market integration in the EU will be getting stronger and stronger. The milk prices in Poland were affecting the prices of that product in other countries, especially in the last period in Estonia, Portugal, Latvia and the Czech Republic. The key countries determining the price variation in Poland are Germany, Ireland, France and Slovakia.

The research results confirm that the factors which affect the spatial price dependencies can be, therefore, strong commercial relations, the time of joining the EU, the distance between the markets or an immediate neighborhood. Besides, one of the factors can also be the availability of cow milk substitutes (e.g., a considerable sheep milk production in Greece). For the significance of those factors, see other publications $[14,26]$.

One must note the limitations to the empirical research. Due to the short series, it was not possible to identify the price relations once the milk quotas were abandoned in 2015. The analysis of the factor would have allowed the researcher to determine whether that factor, important in terms of the milk market operation, has an impact on the directions of changes in the market integration, which, in turn, can provide the evidence for verifying the rate of the process of equalizing the milk prices in Poland.

Author Contributions: Conceptualization, M.R. (Monika Roman) data curation, M.R. (Monika Roman); formal analysis, M.R. (Monika Roman); methodology, M.R. (Monika Roman); resources, M.R. (Monika Roman); visualization, M.R. (Monika Roman), M.R. (Michał Roman); writing—original draft, M.R. (Monika Roman), M.R. (Michał Roman); writing-review and editing, M.R. (Monika Roman); supervision, M.R. (Monika Roman); funding acquisition, M.R. (Monika Roman), M.R. (Michał Roman). All authors have read and agreed to the published version of the manuscript.

Funding: This research received no external funding.

Conflicts of Interest: The authors declare no conflict of interest. 


\section{Appendix A}

Table A1. VAR model for 2005-2018.

\begin{tabular}{|c|c|c|c|c|c|c|c|}
\hline \multicolumn{3}{|c|}{ Coef. } & \multicolumn{2}{|l|}{ Coef. } & \multicolumn{2}{|l|}{ Coef. } & \multirow{2}{*}{$\begin{array}{c}\text { Coef. } \\
\text { PL }\end{array}$} \\
\hline & PL & & PL & & PL & & \\
\hline Constant & $0.252 * * *$ & Constant & $0.239 * * *$ & Constant & $0.185^{* * *}$ & Constant & $0.189^{* * *}$ \\
\hline PL (-1) & $1.161^{* * *}$ & PL $(-1)$ & $1.426^{* * *}$ & PL (-1) & $1.373^{* * *}$ & PL $(-1)$ & $1.393^{* * *}$ \\
\hline PL (-2) & $-0.377^{* * *}$ & PL (-2) & $-0.465^{* * *}$ & PL (-2) & $-0.426^{* * *}$ & PL (-2) & $-0.439^{* * *}$ \\
\hline $\mathrm{BE}(-1)$ & $0.293^{* *}$ & $\mathrm{BG}(-1)$ & $0.181^{* *}$ & $\mathrm{CZ}(-1)$ & $0.222 * *$ & DK $(-1)$ & $0.207^{* * *}$ \\
\hline $\mathrm{BE}(-2)$ & $-0.159^{* * *}$ & $\mathrm{BG}(-2)$ & $-0.214^{* * *}$ & $C Z(-2)$ & $-0.223^{* *}$ & $\mathrm{DK}(-2)$ & $-0.218^{* * *}$ \\
\hline $\mathrm{R}^{2}$ & 0.964 & $\mathrm{R}^{2}$ & 0.960 & $\mathrm{R}^{2}$ & 0.959 & $\mathrm{R}^{2}$ & 0.960 \\
\hline & PL & & PL & & PL & & PL \\
\hline Constant & $0.181^{* * *}$ & Constant & $0.178^{* * *}$ & Constant & $0.165^{* * *}$ & Constant & 0.145 \\
\hline PL $(-1)$ & $1.235^{* * *}$ & PL (-1) & $1.448^{* * *}$ & PL $(-1)$ & $1.306^{* * *}$ & PL (-1) & $1.488^{* * *}$ \\
\hline PL (-2) & $-0.350^{* * *}$ & PL $(-2)$ & $-0.526^{* * *}$ & PL (-2) & $-0.415^{* * *}$ & PL $(-2)$ & $-0.544^{* * *}$ \\
\hline $\mathrm{DE}(-1)$ & $0.361^{* * *}$ & $\mathrm{EE}(-1)$ & 0.11 & $\operatorname{IE}(-1)$ & $0.266^{* * *}$ & $\mathrm{FR}(-1)$ & $0.129^{* * *}$ \\
\hline $\mathrm{DE}(-2)$ & $-0.302^{* * *}$ & $\mathrm{EE}(-2)$ & -0.086 & IE $(-2)$ & $-0.209^{* * *}$ & $\mathrm{FR}(-2)$ & $-0.117^{* *}$ \\
\hline $\mathrm{R}^{2}$ & 0.964 & $\mathrm{R}^{2}$ & 0.958 & $\mathrm{R}^{2}$ & 0.966 & $\mathrm{R}^{2}$ & 0.960 \\
\hline & PL & & PL & & PL & & PL \\
\hline Constant & 0.192 ** & Constant & $0.194^{* * *}$ & Constant & $0.198^{* * *}$ & Constant & $0.19^{* * *}$ \\
\hline PL $(-1)$ & $1.443^{* * *}$ & PL (-1) & $1.443^{* * *}$ & PL $(-1)$ & $1.333^{* * *}$ & PL (-1) & $1.287^{* * *}$ \\
\hline PL (-2) & $-0.499^{* * *}$ & PL (-2) & $-0.534^{* * *}$ & PL (-2) & $-0.359^{* * *}$ & PL (-2) & $-0.311^{* * *}$ \\
\hline IT $(-1)$ & $0.294^{* * *}$ & $\mathrm{LV}(-1)$ & 0.096 & $\mathrm{LT}(-1)$ & $0.223^{* * *}$ & HU (-1) & $0.273^{* * *}$ \\
\hline IT $(-2)$ & $-0.296^{* * *}$ & $\mathrm{LV}(-2)$ & -0.063 & $\mathrm{LT}(-2)$ & $-0.256^{* * *}$ & HU (-2) & $-0.307^{* * *}$ \\
\hline $\mathrm{R}^{2}$ & 0.960 & $\mathrm{R}^{2}$ & 0.959 & $\mathrm{R}^{2}$ & 0.961 & $\mathrm{R}^{2}$ & 0.961 \\
\hline & PL & & PL & & PL & & PL \\
\hline Constant & $0.166^{* * *}$ & Constant & $0.218^{* * *}$ & Constant & $0.261^{* * *}$ & Constant & $0.269^{* * *}$ \\
\hline PL $(-1)$ & $1.437^{* * *}$ & PL (-1) & $1.358^{* * *}$ & PL $(-1)$ & $1.434^{* * *}$ & PL (-1) & $1.354^{* * *}$ \\
\hline PL (-2) & $-0.516^{* * *}$ & PL (-2) & $-0.389 * * *$ & PL (-2) & $-0.463^{* * *}$ & PL $(-2)$ & $-0.389^{* * *}$ \\
\hline NL $(-1)$ & $0.106^{* * *}$ & AT $(-1)$ & $0.251^{* * *}$ & PT (-1) & 0.144 & SI $(-1)$ & $0.300^{* * *}$ \\
\hline NL $(-2)$ & $-0.076^{* * *}$ & $\mathrm{AT}(-2)$ & $-0.284^{* * *}$ & $\mathrm{PT}(-2)$ & $-0.192^{* *}$ & SI $(-2)$ & $-0.346^{* * *}$ \\
\hline $\mathrm{R}^{2}$ & 0.960 & $\mathrm{R}^{2}$ & 0.961 & $\mathrm{R}^{2}$ & 0.960 & $\mathrm{R}^{2}$ & 0.961 \\
\hline & PL & & PL & & PL & & PL \\
\hline Constant & $0.210 * * *$ & Constant & $0.167^{* *}$ & Constant & $0.168^{* * *}$ & Constant & $0.167^{* * *}$ \\
\hline
\end{tabular}


Table A1. Cont.

\begin{tabular}{|c|c|c|c|c|c|c|c|}
\hline & Coef. & & Coef. & & Coef. & & Coef. \\
\hline PL (-1) & $1.351 * * *$ & PL $(-1)$ & $1.492 * * *$ & PL (-1) & $1.416^{* * *}$ & PL $(-1)$ & $1.389^{* * *}$ \\
\hline PL (-2) & $-0.459^{* * *}$ & PL (-2) & $-0.539^{* * *}$ & PL (-2) & $-0.472^{* * *}$ & PL (-2) & $-0.446^{* * *}$ \\
\hline SK $(-1)$ & $0.297^{* * *}$ & FI $(-1)$ & $0.139 * *$ & $\mathrm{SE}(-1)$ & $0.156^{* *}$ & UK (-1) & $0.248^{* * *}$ \\
\hline SK $(-2)$ & $-0.252^{* * *}$ & FI $(-2)$ & $-0.142^{* * *}$ & $\mathrm{SE}(-2)$ & $-0.151^{* *}$ & $\mathrm{UK}(-2)$ & $-0.241^{* * *}$ \\
\hline $\mathrm{R}^{2}$ & $\begin{array}{c}0.960 \\
\text { BE }\end{array}$ & $\mathrm{R}^{2}$ & $\begin{array}{c}0.959 \\
\text { BG }\end{array}$ & $\mathrm{R}^{2}$ & $\begin{array}{c}0.959 \\
C Z\end{array}$ & $\mathrm{R}^{2}$ & $\begin{array}{c}0.962 \\
\text { DK }\end{array}$ \\
\hline Constant & $0.167^{* * *}$ & Constant & 0.138 & Constant & 0.053 & Constant & $0.134^{* *}$ \\
\hline PL $(-1)$ & 0.116 & PL $(-1)$ & $0.322^{* * *}$ & PL (-1) & $0.438^{* * *}$ & PL (-1) & $0.314^{* * *}$ \\
\hline PL (-2) & -0.064 & PL (-2) & $-0.256^{* * *}$ & PL (-2) & $-0.339^{* * *}$ & PL (-2) & $-0.181^{* *}$ \\
\hline $\mathrm{BE}(-1)$ & $1.605^{* * *}$ & BG $(-1)$ & $1.157^{* * *}$ & $\mathrm{CZ}(-1)$ & $1.096^{* * *}$ & DK $(-1)$ & $1.284^{* * *}$ \\
\hline $\mathrm{BE}(-2)$ & $-0.704^{* * *}$ & $\mathrm{BG}(-2)$ & $-0.263^{* * *}$ & $C Z(-2)$ & $-0.209^{* *}$ & DK $(-2)$ & $-0.450 * * *$ \\
\hline $\mathrm{R}^{2}$ & $\begin{array}{c}0.960 \\
\mathrm{DE}\end{array}$ & $\mathrm{R}^{2}$ & $\begin{array}{c}0.943 \\
\mathrm{EE}\end{array}$ & $\mathrm{R}^{2}$ & $\begin{array}{c}0.965 \\
\text { IE }\end{array}$ & $\mathrm{R}^{2}$ & $\begin{array}{c}0.956 \\
\text { FR }\end{array}$ \\
\hline Constant & 0.091 & Constant & 0.069 & Constant & 0.095 & Constant & $0.572^{* * *}$ \\
\hline PL $(-1)$ & 0.171 & PL (-1) & $0.444^{* * *}$ & PL (-1) & $0.487^{* * *}$ & PL (-1) & 0.116 \\
\hline PL (-2) & -0.047 & PL (-2) & $-0.395^{* * *}$ & PL (-2) & $-0.263^{* *}$ & PL $(-2)$ & 0.073 \\
\hline $\mathrm{DE}(-1)$ & $1.478^{* * *}$ & $\mathrm{EE}(-1)$ & $1.349^{* * *}$ & $\mathrm{IE}(-1)$ & $1.320 * * *$ & $\mathrm{FR}(-1)$ & $1.066^{* * *}$ \\
\hline $\mathrm{DE}(-2)$ & $-0.625^{* * *}$ & $\mathrm{EE}(-2)$ & $-0.418^{* * *}$ & IE $(-2)$ & $-0.563^{* * *}$ & $\mathrm{FR}(-2)$ & $-0.413^{* * *}$ \\
\hline $\mathrm{R}^{2}$ & $\begin{array}{c}0.965 \\
\text { IT }\end{array}$ & $\mathrm{R}^{2}$ & $\begin{array}{c}0.973 \\
\text { LV }\end{array}$ & $\mathrm{R}^{2}$ & $\begin{array}{c}0.940 \\
\text { LT }\end{array}$ & $\mathrm{R}^{2}$ & $\begin{array}{c}0.825 \\
\mathrm{HU}\end{array}$ \\
\hline Constant & $0.225^{* * *}$ & Constant & 0.056 & Constant & -0.046 & Constant & 0.031 \\
\hline PL $(-1)$ & $0.164^{* * *}$ & PL (-1) & $0.439^{* * *}$ & PL (-1) & $0.577^{* * *}$ & PL (-1) & $0.428^{* * *}$ \\
\hline PL (-2) & -0.072 & PL (-2) & $-0.345^{* * *}$ & PL (-2) & $-0.384^{* * *}$ & PL (-2) & $-0.295^{* * *}$ \\
\hline IT $(-1)$ & $1.032 * * *$ & $\mathrm{LV}(-1)$ & $1.481^{* * *}$ & $\mathrm{LT}(-1)$ & $1.412 * * *$ & HU (-1) & $1.207^{* * *}$ \\
\hline IT $(-2)$ & $-0.181^{* *}$ & $\mathrm{LV}(-2)$ & $-0.596^{* * *}$ & LT (-2) & $-0.598^{* * *}$ & HU (-2) & $-0.349 * * *$ \\
\hline $\mathrm{R}^{2}$ & $\begin{array}{c}0.946 \\
\mathrm{NL}\end{array}$ & $\mathrm{R}^{2}$ & $\begin{array}{c}0.977 \\
\text { AT }\end{array}$ & $\mathrm{R}^{2}$ & $\begin{array}{c}0.962 \\
\text { PT }\end{array}$ & $\mathrm{R}^{2}$ & $\begin{array}{c}0.968 \\
\text { SI }\end{array}$ \\
\hline Constant & 0.087 & Constant & $0.169^{* * *}$ & Constant & 0.119 & Constant & $0.118^{* * *}$ \\
\hline PL $(-1)$ & $0.611^{* * *}$ & PL (-1) & $0.209^{* * *}$ & PL (-1) & $0.310^{* * *}$ & PL (-1) & 0.098 \\
\hline PL (-2) & $-0.358^{* *}$ & PL $(-2)$ & -0.081 & PL $(-2)$ & $-0.245^{* * *}$ & PL (-2) & -0.035 \\
\hline NL (-1) & $0.987^{* * *}$ & $\mathrm{AT}(-1)$ & $1.363^{* * *}$ & PT (-1) & $0.993^{* * *}$ & SI $(-1)$ & $1.468^{* * *}$ \\
\hline $\mathrm{NL}(-2)$ & $-0.255^{* * *}$ & $\mathrm{AT}(-2)$ & $-0.532 * * *$ & PT (-2) & $-0.092^{* * *}$ & SI $(-2)$ & $-0.567^{* * *}$ \\
\hline $\mathrm{R}^{2}$ & 0.885 & $R^{2}$ & 0.967 & $\mathrm{R}^{2}$ & 0.924 & $\mathrm{R}^{2}$ & 0.975 \\
\hline
\end{tabular}


Table A1. Cont.

\begin{tabular}{|c|c|c|c|c|c|c|c|}
\hline & Coef. & & Coef. & & Coef. & & Coef. \\
\hline & SK & & FI & & SE & & UK \\
\hline Constant & 0.035 & Constant & $0.283^{* * *}$ & Constant & 0.121 & Constant & 0.131 \\
\hline PL (-1) & $0.296^{* * *}$ & PL $(-1)$ & 0.111 & PL (-1) & $0.614^{* * *}$ & PL $(-1)$ & 0.143 \\
\hline PL (-2) & $-0.177^{* * *}$ & PL (-2) & -0.088 & PL (-2) & $-0.534^{* * *}$ & PL (-2) & -0.073 \\
\hline SK $(-1)$ & $1.467^{* * *}$ & FI $(-1)$ & $1.148^{* * *}$ & $\mathrm{SE}(-1)$ & $1.004^{* * *}$ & UK $(-1)$ & $1.246^{* * *}$ \\
\hline SK (-2) & $-0.594^{* * *}$ & FI $(-2)$ & $-0.246^{* * *}$ & SE (-2) & -0.115 & UK $(-2)$ & $-0.353^{* * *}$ \\
\hline $\mathrm{R}^{2}$ & 0.986 & $\mathrm{R}^{2}$ & 0.882 & $\mathrm{R}^{2}$ & 0.945 & $\mathrm{R}^{2}$ & 0.938 \\
\hline
\end{tabular}

${ }^{* *}$ significant at $5 \%$ level, ${ }^{* * *}$ significant at $1 \%$ level. Source: own calculations [10]. 


\section{References}

1. Bakus, Z.; Falkowski, J.; Fertő, I. Milk Market Integration between Hungary and Poland. In Proceedings of the 84th Annual Conference, Edinburgh, Scotland, 29-31 March 2010; Available online: http://ageconsearch. umn.edu/record/91809/files/74Bakucs_falkowski_ferto.pdf (accessed on 15 November 2019).

2. Lence, S.H.; Moschini, G.C.; Santeramo, F.G. Threshold cointegration and spatial price transmission when expectations matter. Agric. Econ. 2018, 49, 25-39. [CrossRef]

3. Roman, M. Spatial integration of the milk market in Poland. Sustainability 2020, 12, 1471. [CrossRef]

4. Sexton, R.J.; Kling, C.L.; Carman, H.F. Market Integration, Efficiency of Arbitrage and Imperfect Competition: Methodology and Application to US Celery. Am. J. Agric. Econ. 1991, 73, 568-580. [CrossRef]

5. Asche, F.; Bremnes, H.; Wessels, C. Product aggregation, market integration, and relationships between prices. Am. J. Agric. Econ. 1999, 81, 568-581. [CrossRef]

6. Serra, T.; Gil, J.; Goodwin, B. Local polynomial fitting and spatial price relationship: Price transmission in EU pork markets. Eur. Rev. Agric. Econ. 2006, 33, 415-436. [CrossRef]

7. Pietrzak, M.; Roman, M. The Problem of Geographical Delimitation of Agri-Food Markets: Evidence from the Butter Market in European Union. Acta Sci. Pol. Oecon. 2018, 17, 85-95. [CrossRef]

8. Jena, P.K. Commodity market integration and price transmission: Empirical evidence from India. Theor. Appl. Econ. 2016, 3, 283-306.

9. Fousekis, P. Price interrelationships in the EU cow milk markets: Evidence from rank-based cointegration tests. Outlook Agric. 2018, 47, 101-107. [CrossRef]

10. Milk Market. Milk Market Observatory. European Commission. Available online: https://ec.europa.eu/ info/food-farming-fisheries/farming/facts-and-figures/markets/overviews/market-observatories/milk_en (accessed on 10 July 2020).

11. Emmanouilides, C.J.; Fousekis, P. Testing for the LOP under nonlinearity: An application to four major EU pork markets. Agric. Econ. 2012, 43, 715-723. [CrossRef]

12. Gil, J.M.; Angulo, A.M.; Zapata, H.O. Further Empirical Evidence of Wheat and Barley Market Integration in the EU. J. Int. Food Agribus. Mark. 2000, 11, 45-61. [CrossRef]

13. Zanias, G.P. Testing for Integration in European Community Agricultural Product Markets. J. Agric. Econ. 1993, 44, 418-427. [CrossRef]

14. Santeramo, F.G.; Di Gioia, L. On the Analysis of Price Dynamics in Agricultural Markets. In Progress in Economics Research; Tavidze, A., Ed.; Nova Science Publishers, Inc.: New York, NY, USA, 2017; pp. $63-90$.

15. Katrakilidis, C. Testing for market integration and the law of one price: An application to selected European milk markets. Int. J. Econ. Res. 2008, 5, 93-104.

16. Fałkowski, J. Price transmission and market power in a transition context: Evidence from the Polish fluid milk sector. Post-Communist Econ. 2010, 22, 513-529. [CrossRef]

17. Reziti, I. Price transmission analysis in the Greek milk market. SPOUDAI J. Econ. Bus. 2014, 64, 75-86.

18. Bor, Ö.; Ismihan, M.; Bayaner, A. Asymmetry in farm-retail price transmission in the Turkish fluid milk market. N. Medit. 2014, 2, 2-8.

19. Rezitis, A.N. Investigating price transmission in the Finnish dairy sector: An asymmetric NARDL approach. Empir. Econ. 2019, 57, 861-900. [CrossRef]

20. Serra, T.; Goodwin, B.K. Price transmission and asymmetric adjustment in the Spanish dairy sector. Applied Economics 2003, 35, 1889-1899. [CrossRef]

21. Bakus, Z.; Fertő, I. Empirical tests of sale theories: Hungarian milk prices. Agric. Econ-Czech 2015, 61, 511-521. [CrossRef]

22. Fernandez-Amador, O.; Baumgartner, J.; Crespo-Cuaresma, J. Milking the prices: The Role of Asymmetries in the Price Transmission Mechanism for Milk Products in Austria; Working Paper 378; Austrian Institute of Economic Research (WIFO): Vienna, Austria, 2010.

23. Waldesenbet, T. Asymmetric price transmission in the Slovak liquid milk market. Agric. Econ. Czech 2013, 59, 512-524. [CrossRef]

24. Acosta, A.; Valdes, A. Vertical Price Transmission of Milk Prices: Are Small Dairy Producers Efficiently Integrated into Markets? Agribusiness 2013, 30, 56-63. [CrossRef]

25. Kharin, S. Price Transmission Analysis: The Case of Milk Products in Russia. AGRIS On-line Pap. Econ. Inform. 2018, 10, 15-23. [CrossRef] 
26. Acosta, A.; Ihle, R.; Robles, M. Spatial Price Transmission of Soaring Milk Prices from Global to Domestic Markets. Agribusiness 2014, 30, 64-73. [CrossRef]

27. Benedek, Z.; Bakucks, Z.; Falkowki, J.; Fertő, I. Intra-EU trade of dairy products: Insights from network analysis. Stud. Agric. Econ. 2017, 119, 91-97. [CrossRef]

28. Zhang, J.; Brown, C.; Dong, X.; Waldron, S. Price transmission in whole milk powder markets: Implications for the Oceania dairy sector of changing market developments. N. Z. J. Agric. Res. 2017, 60, 140-153. [CrossRef]

29. Hillen, J.; von Cramon-Taubadel, S. Protecting the Swiss milk market from foreign price shocks: Public border protection vs. quality differentiation. Agribusiness 2019, 35, 516-536. [CrossRef]

30. Bakcus, Z.; Benedek, Z.; Ferto, I. Spatial Price Transmission and Trade in the European Dairy Sector. AGRIS On-Line Pap. Econ. Inform. 2019, 11, 13-20. [CrossRef]

31. European Dairy Association-EDA. Economic Report 2017/18. Available online: http://eda.euromilk.org/ fileadmin/user_upload/Public_Documents/Facts_and_Figures/EDA_Economic_Report_2017.pdf (accessed on 7 January 2020).

32. Wysokiński, M.; Baran, J.; Florkowski, J. Concentration of milk production in Poland. In Proceedings of the 2015 International Conference "Economic Science for Rural Development", Jelgava, Latvia, 23-24 April 2015; pp. 93-104.

33. Eurostat. Milk and Milk Products-30 Years of Quotas. Available online: https://ec.europa.eu/ eurostat/statistics-explained/index.php/Archive:Milk_and_milk_products_-30_years_of_quotas (accessed on 3 September 2019).

34. FAO. Data. Production. Livestock Primary. Available online: http://www.fao.org/faostat/en/\#data/QL (accessed on 10 July 2020).

35. Dickey, D.A.; Fuller, W.A. Distribution of the estimators for autoregressive time series with a unit root. J. Am. Stat. Assoc. 1979, 74, 427-431.

36. Rapsomanikis, G.; Hallam, D.; Conforti, P. Market integration and price transmission in selected food and cash crop markets of developing countries: Review and applications. In FAO, Commodity Market Review; FAO Commodities and Trade Division: Rome, Italy, 2004; Volume 7, pp. 1-21.

37. Sims, C.A. Macroeconomics and Reality. Econometrica 1980, 49, 1-48. [CrossRef]

38. Mills, T.C. The Econometric Modeling of Financial Time Series; Cambridge University Press: Cambridge, UK, 2002.

39. Kusideł, E. Modelowanie Wektorowo-Autoregresyjne VAR. Metodologia I Zastosowanie W Badaniach Ekonomicznych; Absolwent Press: Lodz, Poland, 2000. (In Polish)

40. Granger, C.W.J. Investigating Causal Relations by Econometric Models and Cross-spectral Methods. Econometrica 1969, 37, 424-438. [CrossRef]

41. Hamulczuk, M. Spatial integration of agricultural commodity markets-Methodological problems. Probl. Agric. Econ. 2020, 263, 32-52. [CrossRef]

42. Roman, M. Problems with the Logistics of Supplying Dairy Plants with Milk. Ann. Pol. Assoc. Agric. Agribus. Econ. 2018, 20, 162-167. [CrossRef]

43. Laborde, D.; Martin, W.; Swinnen, J.; Vos, R. COVID-19 risks to global food security. Science 2020, 369, 500-502. [CrossRef] [PubMed]

Publisher's Note: MDPI stays neutral with regard to jurisdictional claims in published maps and institutional affiliations.

(C) 2020 by the authors. Licensee MDPI, Basel, Switzerland. This article is an open access article distributed under the terms and conditions of the Creative Commons Attribution (CC BY) license (http://creativecommons.org/licenses/by/4.0/). 